\title{
Effect of phytoestrogens on basal and GnRH-induced gonadotropin secretion
}

\author{
Sergio A Arispe, Betty Adams and Thomas E Adams
}

Department of Animal Science, University of California, Davis, One Shields Avenue, Davis, California 95616, USA

Correspondence should be addressed to T E Adams

Email

teadams@ucdavis.edu

\begin{abstract}
Plant-derived estrogens (phytoestrogens, PEs), like endogenous estrogens, affect a diverse array of tissues, including the bone, uterus, mammary gland, and components of the neural and cardiovascular systems. We hypothesized that PEs act directly at pituitary loci to attenuate basal FSH secretion and increase gonadotrope sensitivity to GnRH. To examine the effect of PEs on basal secretion and total production of FSH, ovine pituitary cells were incubated with PEs for $48 \mathrm{~h}$. Conditioned media and cell extract were collected and assayed for FSH. Estradiol $\left(E_{2}\right)$ and some PEs significantly decreased basal secretion of FSH. The most potent PEs in this regard were coumestrol (CM), zearalenone (ZR), and genistein (GN). The specificity of PE-induced suppression of basal FSH was indicated by the absence of suppression in cells coincubated with PEs and an estrogen receptor (ER) blocker (ICI 182 780; ICI). Secretion of LH during stimulation by a $\mathrm{GnRH}$ agonist ( $\mathrm{GnRH}-\mathrm{A}$ ) was used as a measure of gonadotrope responsiveness. Incubation of cells for $12 \mathrm{~h}$ with $\mathrm{E}_{2}, \mathrm{CM}, \mathrm{ZR}, \mathrm{GN}$, or daidzein (DZ) enhanced the magnitude and sensitivity of $\mathrm{LH}$ secretion during subsequent exposure to graded levels of a GnRH-A. The $E_{2}$ - and PE-dependent augmentation of gonadotrope responsiveness was nearly fully blocked during coincubation with ICl. Collectively, these data demonstrate that selected PEs (CM, ZR, and $G N$ ), like $E_{2}$, decrease basal secretion of FSH, reduce total FSH production, and enhance GnRH-A-induced LH secretion in a manner that is dependent on the ER.
\end{abstract} \author{
Key Words \\ $\mathrm{LH}$ \\ - $\mathrm{FSH}$ \\ - cell culture \\ - phytoestrogens \\ - estradiol \\ - estrogen receptor \\ - ovine pituitary cells
}

\section{Introduction}

Phytoestrogens (PEs) are nonsteroidal, organic compounds that are bound by one or both of the estrogen receptor (ER) isoforms, $\mathrm{ER} \alpha$ and $\mathrm{ER} \beta$ (Kuiper et al. 1998). Although nonsteroidal, the structure of these plantderived compounds generally includes a phenolic ring resembling the aromatic ring of ovarian-derived estrogens, such as $17 \beta$-estradiol $\left(\mathrm{E}_{2}\right)$.

Endogenous estrogens affect a diverse array of tissues including the gonadotrope cells of the pituitary. These cells synthesize the gonadotropic hormones, luteinizing hormone (LH), and follicle-stimulating hormone (FSH), which have important roles in reproduction. Specifically, in females FSH stimulates follicular growth and maturation, whereas LH promotes steroidogenesis and ovulation. Although estrogens can affect gonadotropin synthesis and secretion by influencing gonadotropin-releasing hormone (GnRH) release from hypothalamic loci, direct action of estrogens on gonadotrope cells is suggested by experiments using in vivo and in vitro models in which pituitary tissue is physically separated from hypothalamic inputs 
(Clarke \& Cummins 1984). Indeed, effects of estrogens on basal and GnRH-stimulated gonadotropin secretion are evident in cell culture using ovine or rodent pituitary cells (Huang \& Miller 1980). Although the effect of endogenous estrogens on gonadotrope function is well recognized, much less is known regarding the effect of PEs on the synthesis and secretion of FSH. This may be a particularly important concern in animal production systems, because several common forages, including alfalfa, clover, lupin, and some grains, contain high concentrations of PEs (Dixon 2004). In addition, the rumen and intestinal microbiota of domestic livestock species may enhance the estrogenic potency of feedstuffs by transforming plant precursors into active PEs (Zhou et al. 2009).

The potential effects of PEs on the reproductive efficiency of livestock is suggested by reports that female sheep and cattle grazing on subterranean clover (Trifolium subterran) or alfalfa (Medicago sativa) became infertile (Bennetts et al. 1946, Moule et al. 1963). These effects of PEs on reproduction are likely to reflect PE-dependent change in the ER function. Indeed, Mathieson \& Kutts (1980) report that genistein (GN) and coumestrol (CM) compete with $\mathrm{E}_{2}$ for binding sites in hypothalamic and pituitary tissue of sheep.

In the studies reported here, we examine the physiological effect of PEs commonly present in feedstuffs provided to domestic animals. Our particular objective was to determine the effect of PEs on basal secretion of FSH. In addition, we assessed the effect of PEs on GnRHinduced LH secretion from ovine pituitary cells.

\section{Materials and methods}

\section{Reagents and supplies}

Calcium and magnesium-free (CMF) Hanks balanced salt solution (HBSS), and medium 199 (without phenol red, L-glutamine, or $\mathrm{NaHCO}_{3}$; M199) were obtained from Sigma-Aldrich. Bovine insulin, the GnRH agonist (D-Ala ${ }^{6}$, des-Gly ${ }^{10} \mathrm{GnRH}$ ethylamide; GnRH-A), pancreatin, the ER antagonist (ICI 780 182; fulvestrant), and most PEs were also purchased from Sigma-Aldrich. The PE, daidzein (DZ), was purchased from Tocris Bioscience (Ellisville, MO, USA). The antifungal drug, fungizone, and the two antibiotics, gentamycin sulfate and penicillin/streptomycin, were obtained from HyClone (Logan, UT, USA), Mediatech (Manassas, VA, USA), and Gibco respectively. Collagenase (type-I; Worthington Biochemical Corporation, Lakewood, NJ, USA), L-glutamine (Invitrogen), BSA (fraction V; EMD Chemicals, Gibbstown, NJ, USA), and $\mathrm{E}_{2}$ (United States Biochemical Corp., Cleveland, $\mathrm{OH}$, USA) were obtained from established vendors.

\section{Cell culture}

Pituitary tissue was collected from castrated male yearling sheep euthanized at a local abattoir by electrical stunning and exsanguination. Tissue was collected within $10 \mathrm{~min}$ of euthanasia and immersed in low calcium, magnesium-free (LCMF) HBSS. LCMF HBSS was prepared by supplementing CMF HBSS with $\mathrm{CaCl}_{2} \cdot \mathrm{H}_{2} \mathrm{O}, 1 \%$ BSA, $25 \mathrm{mM}$ HEPES, $0.035 \% \mathrm{NaHCO}_{3}$, and penicillin/ streptomycin (100 units/ml). The tissue was dissociated into component cells using a modification of the procedure developed by Huang \& Miller (1980). Briefly, anterior pituitary tissue was dissected free of connective tissue and the posterior pituitary and sliced into $0.5 \mathrm{~mm}$ sections using a Stadie-Riggs tissue slicer. The pituitary slices were minced into roughly $2 \mathrm{~mm}^{2}$ with scissors. The minced tissue from five pituitary glands was combined and washed five times with LCMF HBSS before resuspension into $66 \mathrm{ml}$ LCMF HBSS containing $200 \mathrm{mg}$ collagenase $(290 \mathrm{U} / \mathrm{mg})$. The tissue suspension was gently agitated in a rotary shaker $\left(90\right.$ r.p.m.) at $37^{\circ} \mathrm{C}$ for $90 \mathrm{~min}$. After incubation with collagenase, the partially digested tissue was pelleted by centrifugation ( $400 \boldsymbol{g}$ for $4 \mathrm{~min}$ ). The collagenase containing supernatant was decanted and tissue fragments were resuspended in $60 \mathrm{ml}$ CMF HBSS containing $0.25 \%$ pancreatin. Tissue fragments were incubated with pancreatin for $35 \mathrm{~min}$ at $37^{\circ} \mathrm{C}$ with gentle agitation. At the conclusion of enzyme treatment, undigested tissue was removed by passage of the cell suspension through a nylon mesh filter. Dispersed cells were pelleted by centrifugation $(400 \boldsymbol{g}$ for $4 \mathrm{~min})$ and washed four times with CMF HBSS. Cell yield was assessed using a hemocytometer and viability was determined by dye exclusion. Average yield was $200 \times 10^{6}$ cells/g initial tissue $(n=5)$, with a viability $>90 \%($ mean $=95.5 \%)$. After the final wash with CMF HBSS, the cell pellet was suspended using M199 containing $\mathrm{NaHCO}_{3}(2.2 \mathrm{~g} / \mathrm{l})$, L-glutamine $(200 \mathrm{mM})$, insulin $(5 \mu \mathrm{g} / \mathrm{ml})$, gentamycin sulfate $(60 \mu \mathrm{g} / \mathrm{ml})$, penicillin/streptomycin (100 units/ml), fungizone $(500 \mathrm{ng} / \mathrm{ml})$, HEPES sodium salt $(25 \mathrm{mM})$, and $10 \%$ serum collected from castrated male sheep (M199+ $10 \%$ wether serum (WS)). One milliliter aliquot of the cell suspension $\left(0.5 \times 10^{6}\right.$ cells $\left./ \mathrm{ml}\right)$ was used to seed the 24-well culture plates. The seeded plates were placed in a water-jacketed incubator and cells were allowed to attach during $36-48 \mathrm{~h}$ culture at $37^{\circ} \mathrm{C}$ in a humidified atmosphere of $5 \% \mathrm{CO}_{2}$ and air.

Published by Bioscientifica Ltd 


\section{Experimental procedure}

The effect of $\mathrm{E}_{2}$ and PEs on the basal secretion of FSH from attached pituitary cells was assessed by removing conditioned culture media, washing each well with $1 \mathrm{ml}$ M199+10\% WS and, finally adding $1 \mathrm{ml} \mathrm{M199+10 \%} \mathrm{WS}$ the appropriate concentration of test compound $\left(\mathrm{E}_{2}\right.$ with $\mathrm{PE})$. The PEs (CM, zearalenone (ZR), GN, DZ, resveratrol $(\mathrm{RV})$, biochanin A (BA), and enterolactone (EL)) were diluted in DMSO to working concentrations $(0.001-1.0 \mu \mathrm{M})$ using M199+10\% WS (final DMSO concentration was $0.2 \%$ ). Vehicle also contained DMSO. We found no evidence that DMSO at the concentration (0.2\%) used in these studies influenced the results. Conditioned media was collected after $48 \mathrm{~h}$ incubation with vehicle, $\mathrm{E}_{2}$, or PE. In some experiments vehicle, $\mathrm{E}_{2}$, or PEs were coincubated with an ER antagonist (ICI 182 780). After removal of conditioned media, cellular content of FSH was assessed by adding $1 \mathrm{ml}$ of cold $0.01 \mathrm{M}$ PBS to each well and rapidly freezing plates at $-85^{\circ} \mathrm{C}$. The attached cells were lysed by repeated freezing and thawing as described in previous studies (Adams et al. 1979). PBS was collected after the fourth freeze-thaw cycle and used to determine cellular FSH content. The concentration was then combined with basal secretion to determine the total production of FSH.

The effect of $E_{2}$ and PEs on the sensitivity and magnitude of GnRH-A-induced LH secretion was assessed using a related experimental paradigm. Briefly, after a $48 \mathrm{~h}$ attachment period, conditioned media was removed and replaced with $1 \mathrm{ml}$ media containing the desired concentration of $\mathrm{E}_{2}, \mathrm{PE}$, and/or ICI. After $12 \mathrm{~h}$ incubation with test compounds, wells were flushed twice with $1 \mathrm{ml}$ media, with final addition of $1 \mathrm{ml}$ media containing vehicle or the appropriate concentration of GnRH-A (0.1-1000 pM). Media from treated wells was collected after a $6 \mathrm{~h}$ incubation with the GnRH-A.

\section{Measurement of LH and FSH}

The concentrations of LH and FSH were determined by RIA following procedures described previously (Adams et al. 1975, 1988). The ovine FSH (NIADDK-oFSH-20) and LH (NIADDK-oLH-26) standard preparations were kindly provided by NIH.

\section{Statistical analysis}

The statistical significance of experimental observations was assessed using the mixed model procedure lmer() in R (Bates \& Maechler 2009). For studies of basal FSH secretion, fixed effects included treatment, experiment, and treatmentexperiment interaction, while plate was included as a random effect. In contrast, GnRH-A-induced LH secretion was analyzed using a model that included the fixed effects of treatment, GnRH, and treatment-GnRH-A interaction; experiment and experiment-GnRH-A, while plate and plate-GnRH-A were included as random effects. The likelihood-ratio-test was used to determine the significance of the fixed effects $(P<0.05)$ and competing models where fitted using maximum likelihood. Contrasts were setup to determine the mean comparisons against the negative control (vehicle) and positive controls (0.05 and $5 \mathrm{nM} \mathrm{E}_{2}$ ). The Bonferroni correction was used to control the type 2 error rate.

\section{Results}

\section{Effect of $E_{2}$ and PEs on basal gonadotropin parameters}

To determine the effects of $\mathrm{E}_{2}$ and PEs on basal secretion of FSH and total FSH production, we incubated ovine pituitary cells with increasing concentrations of $\mathrm{E}_{2}$ and PEs for $48 \mathrm{~h}$. Physiologic (0.05 nM) and pharmacologic (5 nM) concentrations of $\mathrm{E}_{2}$ markedly reduced basal secretion of FSH and significantly reduced total FSH production (Fig. 1). Some, but not all, PEs had a similar effect. The two most potent PEs in this regard were CM and ZR. Neither DZ, RV, BA, nor EL affected basal FSH secretion or total production of FSH in this ovine pituitary cells culture system.

\section{Role of ER on basal FSH parameters}

To assess the role of estrogen receptors in expression of the effects of $E_{2}$ and PEs, we coincubated pituitary cells with $E_{2}$ or PEs and ICI 182780 (ICI), a potent estrogen receptor antagonist. The results of these coincubation studies clearly demonstrate that estrogen-dependent suppression of both FSH parameters is mediated by ER (Fig. 2). Indeed, the normal estrogen-induced reduction in FSH secretion was blocked, or markedly attenuated in cells receiving the estrogenic stimulus in combination with ICI. It is important to note that ICI not only did block the response induced by $\mathrm{E}_{2}$ but also prevented the PE-induced decrease in basal FSH secretion (Fig. 2A). Similarly, estrogendepended decrease in total FSH production was prevented in cells receiving estrogen and ICI concurrently (Fig. 2B).

\section{Effect of $E_{2}$ and PEs on gonadotrope responsiveness}

In another set of studies, we examined the effect of $E_{2}$ and PEs on the magnitude and sensitivity of GnRH-A-induced

Published by Bioscientifica Ltd 
A
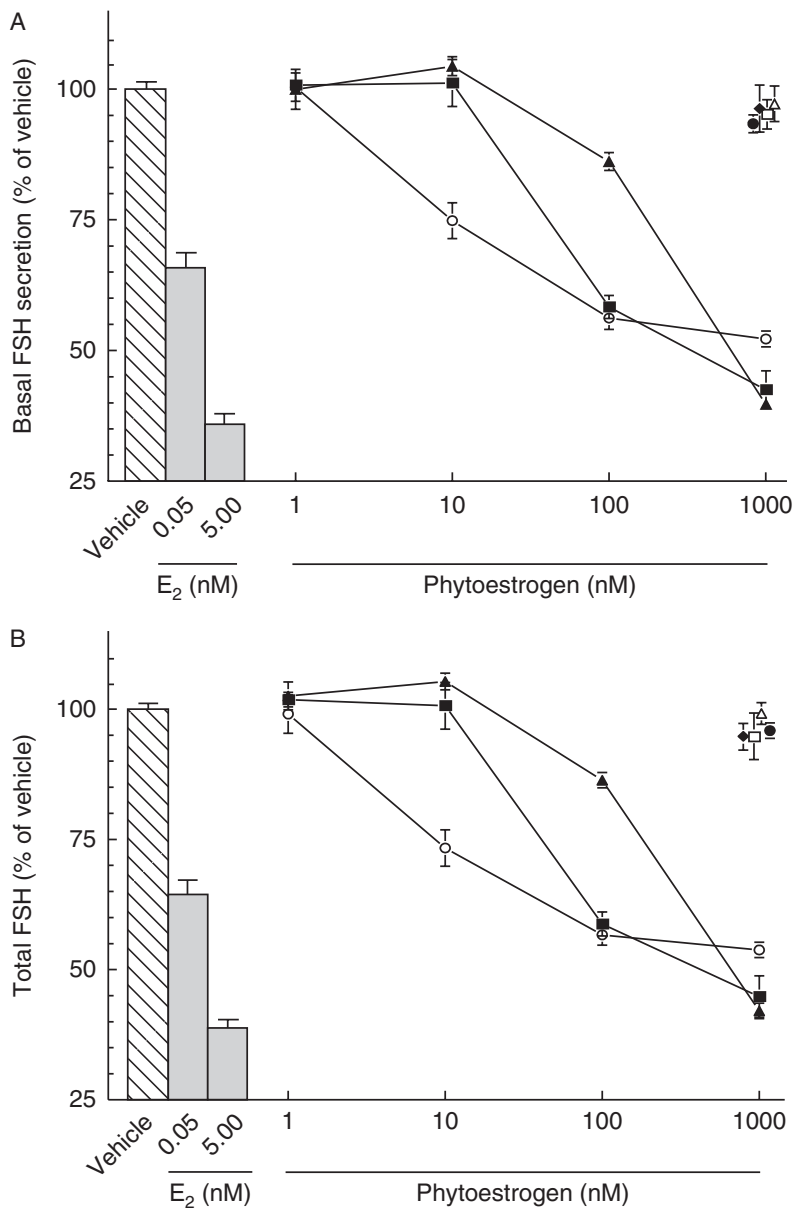

Figure 1

Effect of estrogenic stimuli on (A) basal FSH secretion and (B) total FSH production of ovine pituitary cells treated with various concentrations of estradiol $\left(\mathrm{E}_{2}\right)$, coumestrol $(-\mathbf{-}-)$, zearalenone $(-\mathrm{O}-)$, genistein $(-\mathbf{\Delta}-)$, daidzein $(-\square-)$, resveratrol $(-\bullet-)$, biochanin $A(-\Delta-)$, or enterolactone $(--)$ for $48 \mathrm{~h}$. Control wells were treated with vehicle alone and yielded $49.9 \pm 1.2$ and $61.6 \pm 0.7 \mathrm{ng} / \mathrm{ml}$ for basal secretion and total production respectively.

LH secretion. As described in detail in the Materials and methods section, attached cells were pretreated with $\mathrm{E}_{2}$, $\mathrm{PE}$, and/or ICI for $12 \mathrm{~h}$ and then exposed to vehicle or various concentrations of GnRH-A for $6 \mathrm{~h}$. The magnitude and sensitivity of GnRH-A-induced LH secretion during the $6 \mathrm{~h}$ treatment period were determined. The effect of $\mathrm{E}_{2}$, ICI, and selected PEs on gonadotrope responsiveness is illustrated in Fig. 3. These data clearly demonstrate that pretreatment with physiological concentration of $\mathrm{E}_{2}$ significantly enhanced the magnitude and sensitivity of LH secretion induced by GnRH-A. Pretreatment of pituitary cells with selected PEs, including CM, ZR, GN, or $\mathrm{DZ}$, resulted in similar augmentation of gonadotrope responsiveness. The enhanced gonadotrope responsiveness resulting from pretreatment with $\mathrm{E}_{2}$ or PEs was markedly attenuated in cells coincubated with estrogenic stimuli and ICI. Interestingly, pretreatment with ICI alone resulted in a modest, but consistent increase in both maximal GnRH-A dependent LH secretion and gonadotrope sensitivity.

The data presented in Table 1 demonstrate that $12 \mathrm{~h}$ pretreatment of pituitary cells with $\mathrm{E}_{2}$ or PEs did not affect subsequent basal secretion of LH. Conversely, the magnitude of LH secretion induced by $1000 \mathrm{pM}$ GnRH-A was significantly increased by prior exposure to physiological
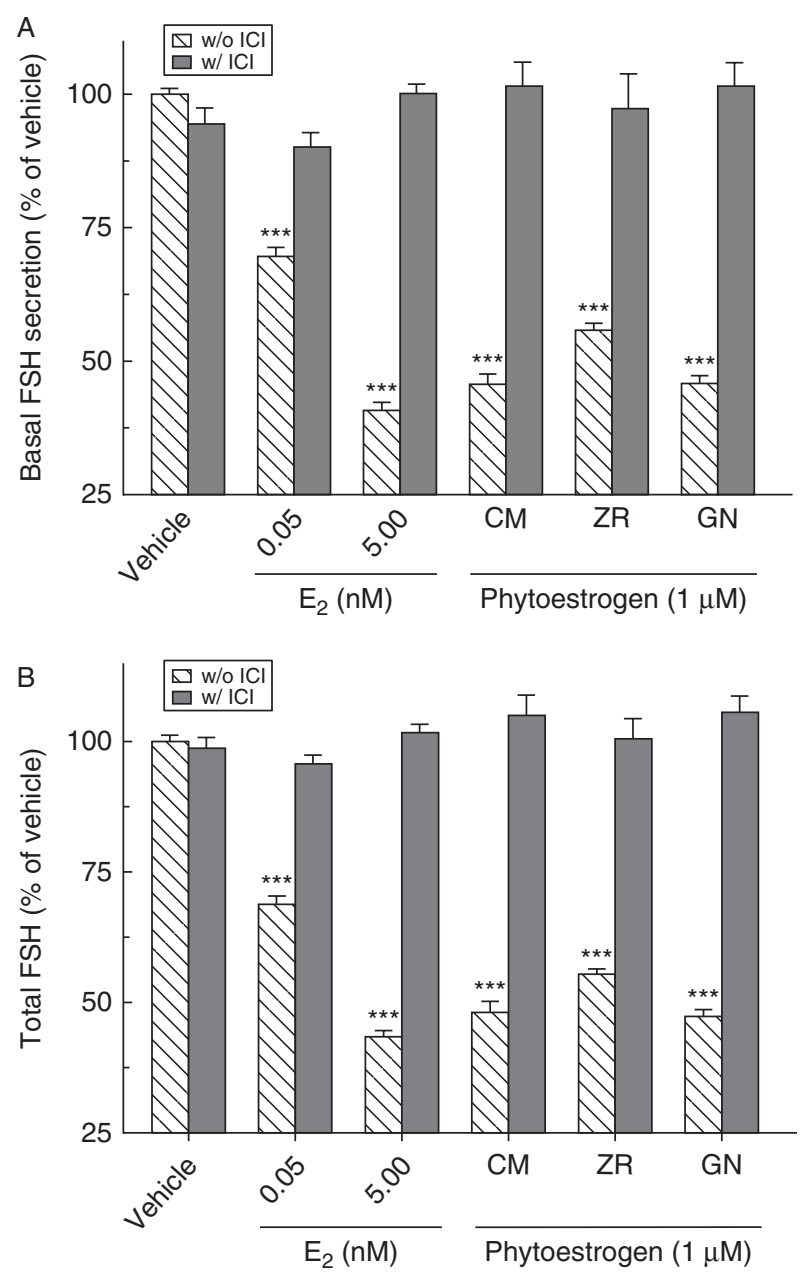

Figure 2

Effect of the estrogen receptor antagonist ICI $182780(\mathrm{ICl} ; 1 \mu \mathrm{M})$ on the decrease in (A) basal secretion of FSH and (B) total FSH production induced by estradiol $\left(E_{2}\right)$, coumestrol $(C M)$, zearalenone $(Z R)$, or genistein $(G N)$. Anterior pituitary cells were treated with vehicle, $E_{2}(0.05$ or $5.0 \mathrm{nM})$, or $1 \mu \mathrm{M}$ concentration of the PEs for $48 \mathrm{~h}$ either alone or in combination with $1 \mu \mathrm{M} \mathrm{ICl}$. Control wells were treated with vehicle alone and yielded $49.9 \pm 1.2$ and $61.6 \pm 0.7 \mathrm{ng} / \mathrm{ml}$ for basal secretion and total production respectively. ${ }^{* *}, P<0.001$ compared to Vehicle $w /$ and $w / o \mathrm{ICl}$. 


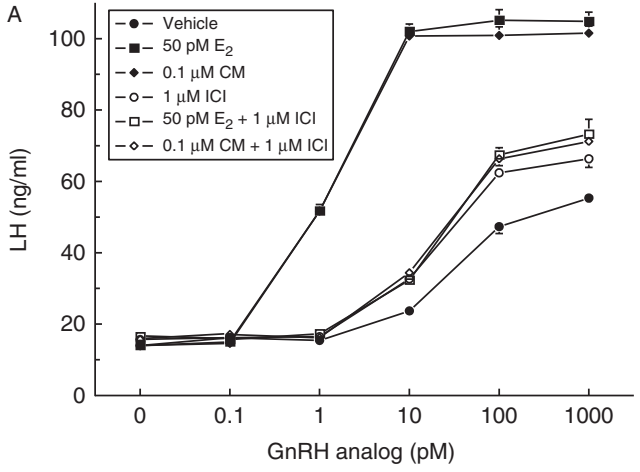

B
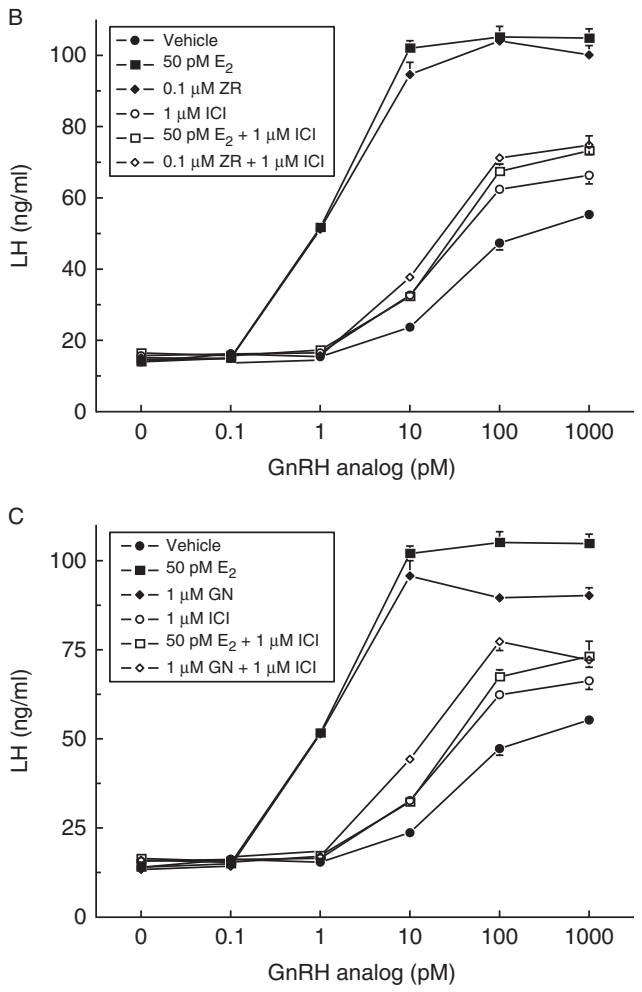

D

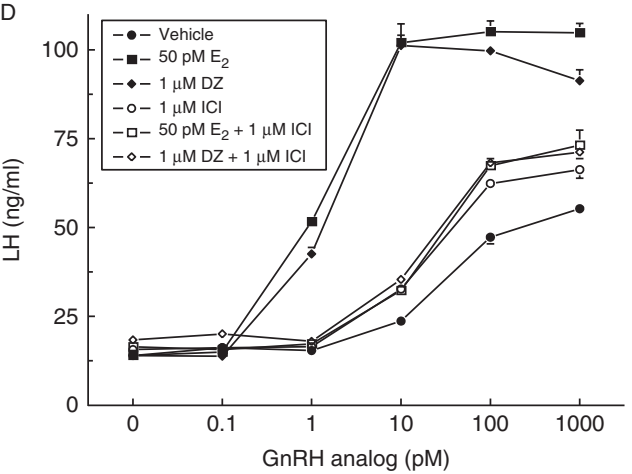

Figure 3

Effect of estradiol $\left(E_{2}\right)$, ICl $182780(\mathrm{ICI})$, and selected PEs (A) coumestrol $(C M)$, (B) zearalenone (ZN), (C) genistein (GN), and (D) daidzein (DZ) on the magnitude and sensitivity of GnRH agonist-induced LH secretion from ovine pituitary cells. Data for vehicle, $\mathrm{E}_{2}$, and $\mathrm{ICl}$ are identical and were included as a reference for the treatments. Printed in Great Britain concentration of $\mathrm{E}_{2}(50 \mathrm{pM})$. Pretreatment with PEs similarly increased the magnitude of GnRH-A-induced LH secretion. The PEs with the highest potency in this regard were $\mathrm{CM}$ and $\mathrm{ZR}$, both of which induced the greatest enhancement of secretory response at a $\mathrm{PE}$ concentration of $0.1 \mu \mathrm{M}$. The augmented response induced by GN or DZ was somewhat less robust in that $1 \mu \mathrm{M}$ concentration of the $\mathrm{PE}$ was required to elicit significant enhancement of gonadotrope responsiveness.

In addition to affecting the magnitude of $\mathrm{LH}$ secretion induced by high levels of GnRH or GnRH-A stimulation, prior exposure to $\mathrm{E}_{2}$ or PEs may also affect the sensitivity of the response. We quantified gonadotrope sensitivity by determining the concentration of GnRH-A required to establish the half maximal secretory response. The results of these analyses are presented in Table 2 . These data demonstrate that the concentration of GnRH-A required to induce half maximal LH secretion from control cells pretreated with vehicle alone was $35.5 \pm 2.8$ pM. Pretreatment of pituitary cells with physiological concentrations of $\mathrm{E}_{2}(50 \mathrm{pM})$ markedly enhanced gonadotrope sensitivity and, as a consequence, lowered the GnRH-A stimulus required to establish the half maximal response to $1.3 \pm 2.8 \mathrm{pM}$. Pretreatment with selected PEs had a similar effect on gonadotrope sensitivity, with CM and ZR being

Table 1 Effect of estradiol $\left(E_{2}\right)$ and increasing concentrations of coumestrol (CM) or zearalenone (ZR) on basal and GnRHagonist ( $\mathrm{GnRH}-\mathrm{A}$ )-induced $\mathrm{LH}$ secretion. After a $48 \mathrm{~h}$ period of attachment, pituitary cells were incubated for $12 \mathrm{~h}$ with vehicle, $E_{2}$, or increasing concentrations of $C M$ or $Z R$. The magnitude of LH secretion induced by $1 \mathrm{nM} \mathrm{GnRH-A}$ was assessed during the $6 \mathrm{~h}$ period that followed estrogen pretreatment. Values represent the mean \pm s.E.M. of at least three replicates of the experiment

\begin{tabular}{|c|c|c|}
\hline Pretreatment & $\begin{array}{l}\text { Basal LH } \\
\text { (ng/well) }\end{array}$ & $\begin{array}{c}1 \text { nM GnRH-A-induced LH } \\
\text { secretion (ng/well) }\end{array}$ \\
\hline Vehicle & $14.6 \pm 0.5^{*}$ & $45.9 \pm 1.9 *$ \\
\hline $50 \mathrm{pM} \mathrm{E}_{2}$ & $14.6 \pm 0.7 *$ & $90.2 \pm 5.5^{\dagger}$ \\
\hline \multicolumn{3}{|l|}{ Coumestrol (nM) } \\
\hline 10 & $\begin{array}{l}11.6 \pm 0.6^{*} \\
13.2 \pm 0.8^{*}\end{array}$ & $\begin{array}{l}42.4 \pm 1.0^{*} \\
67.9 \pm 1.4^{\dagger}\end{array}$ \\
\hline 100 & $12.1 \pm 0.5^{*}$ & $83.1 \pm 3.7^{\dagger}$ \\
\hline 1000 & $12.1 \pm 0.8^{*}$ & $78.7 \pm 4.1^{\dagger}$ \\
\hline \multicolumn{3}{|l|}{ Zearalanone (nM) } \\
\hline 1 & $11.5 \pm 0.7^{*}$ & $35.8 \pm 1.0 *$ \\
\hline 10 & $13.5 \pm 0.3^{*}$ & $63.4 \pm 4.1^{\ddagger}$ \\
\hline 100 & $11.3 \pm 0.8^{*}$ & $77.3 \pm 1.2^{\dagger}$ \\
\hline 1000 & $12.1 \pm 0.4^{*}$ & $75.6 \pm 4.1^{\dagger}$ \\
\hline
\end{tabular}

${ }^{*},+, \pm$ Values within a column with differing superscripts differed significantly $(P<0.05)$.

Published by Bioscientifica Ltd. 
Table 2 Effect of estradiol $\left(E_{2}\right)$, selected phytoestrogens (PEs), and/or ICI $182780(\mathrm{ICI})$, an estrogen receptor antagonist, on the sensitivity of $\mathrm{GnRH}$ agonist ( $\mathrm{GnRH}-\mathrm{A}$ )-induced $\mathrm{LH}$ secretion. The concentration of GnRH-A that effected half maximal $\mathrm{LH}$ secretion was used as measure of gonadotrope sensitivity. After a $48 \mathrm{~h}$ period of attachment pituitary cells were incubated for $12 \mathrm{~h}$ with vehicle, $\mathrm{E}_{2}(50 \mathrm{pM})$, coumestrol (CM; $\left.0.1 \mu \mathrm{M}\right)$, zearalenone (ZR; $0.1 \mu \mathrm{M})$, genistein $(\mathrm{GN}$ : $1 \mu \mathrm{M})$, or daidzein (DZ; $1 \mu \mathrm{M} \mathrm{DZ}$ ) alone or in combination with $1 \mu \mathrm{M} \mathrm{ICl}$. The magnitude of GnRH-A induced LH secretion was assessed during the $6 \mathrm{~h}$ period that followed estrogen pretreatment. Values represent the mean \pm s.E.M. of at least three replicates of the experiment

\begin{tabular}{|c|c|c|}
\hline \multicolumn{2}{|c|}{ Pretreatment } & \multirow[b]{2}{*}{ GnRH-A $(p M)^{a}$} \\
\hline Estrogen & ICI $182780(1 \mu \mathrm{M})$ & \\
\hline Vehicle & Vehicle & $35.5 \pm 2.8^{*}$ \\
\hline Vehicle & $\mathrm{ICI}$ & $19.1 \pm 2.8^{\ddagger}$ \\
\hline$E_{2}(50 p M)$ & Vehicle & $1.3 \pm 2.8^{\dagger}$ \\
\hline $\mathrm{E}_{2}(50 \mathrm{pM})$ & $\mathrm{ICl}$ & $23.7 \pm 2.8^{\ddagger}$ \\
\hline $\mathrm{CM}(0.1 \mu \mathrm{M})$ & Vehicle & $1.2 \pm 2.8^{\dagger}$ \\
\hline $\mathrm{CM}(0.1 \mu \mathrm{M})$ & $\mathrm{ICl}$ & $20.0 \pm 2.8^{\ddagger}$ \\
\hline $\mathrm{ZR}(0.1 \mu \mathrm{M})$ & Vehicle & $1.3 \pm 2.8^{\dagger}$ \\
\hline $\mathrm{ZR}(0.1 \mu \mathrm{M})$ & $\mathrm{ICl}$ & $16.7 \pm 2.8^{\ddagger}$ \\
\hline $\mathrm{GN}(1 \mu \mathrm{M})$ & Vehicle & $0.9 \pm 2.8^{\dagger}$ \\
\hline GN $(1 \mu \mathrm{M})$ & $\mathrm{ICl}$ & $10.3 \pm 2.8^{\S}$ \\
\hline $\mathrm{DZ}(1 \mu \mathrm{M})$ & Vehicle & $1.4 \pm 2.8^{\dagger}$ \\
\hline $\mathrm{DZ}(1 \mu \mathrm{M})$ & $\mathrm{ICI}$ & $20.0 \pm 2.8^{\ddagger}$ \\
\hline
\end{tabular}

${ }^{*}, t, \neq, \$$ Values with differing superscripts differed significantly $(P<0.05)$. ${ }^{a}$ Concentration of GnRH-A required to induce half maximal LH secretion.

most effective in this regard. It is again important to note that the augmentation of gonadotrope sensitivity induced by $\mathrm{E}_{2}$ and PEs was partially reversed in cells exposed to estrogen together with ICI during the pretreatment period. The other PEs examined, RV, BA, and EL, did not affect either gonadotrope sensitivity or maximal agonist-induced response, even at maximum concentrations $(1 \mu \mathrm{M})$.

\section{Discussion}

The results presented here demonstrate that PEs exert estrogen-like effects at pituitary loci. We demonstrated that PEs, like $\mathrm{E}_{2}$ itself, suppressed basal FSH secretion and also reduce total FSH production. Similarly, we demonstrated that PE treatments exhibited estrogen-like activity and increased the secretory response induced by GnRH-A, also in a dose-dependent manner. Furthermore, we combined estrogenic stimuli with the 'pure' ER antagonist, ICI, to illustrate that the PE-mediated effects on basal FSH secretion and GnRH-A induced LH secretion are ER-dependent. Interestingly, ICI displayed estrogenic and anti-estrogenic effects on gonadotrope function in the ovine pituitary cell culture system used in our study.

Estrogenic stimuli are known to attenuate basal FSH secretion and residual intracellular FSH and thereby decrease total FSH production. This has been demonstrated in several species using both in vivo and in vitro models (Lindzey et al. 2006, Arreguin-Arevalo et al. 2007). Groups using ovine pituitary cells in culture have clearly demonstrated that treatment with $\mathrm{E}_{2}$ attenuates $\mathrm{FSH}$ secretion and intracellular synthesis (Miller et al. 1977, Huang \& Miller 1980, Nett et al. 2002). In particular, $\mathrm{E}_{2}$ suppresses these parameters by decreasing FSH $\beta$ expression (Miller \& Miller 1996, Baratta et al. 2001). Unfortunately, the specific mechanism by which $\mathrm{E}_{2}$ exerts this effect is not clear. However, Baratta et al. (2001) demonstrated that $\mathrm{E}_{2}$ decreased activin $\beta$, a growth factor necessary for normal FSH $\beta$ transcription. They concluded that $E_{2}$ indirectly regulates FSH $\beta$ transcription by decreasing activin $\beta$ and, ultimately, decreasing synthesis and secretion of FSH. Our results are consistent with this model.

It is well established that estrogenic stimuli increase gonadotrope responsiveness. Elevated $\mathrm{E}_{2}$ concentrations immediately preceding ovulation increase $\mathrm{GnRH}$ receptor (GnRHR) expression in gonadotrope cells in sheep (Sakurai \& Adams 1991, Turzillo et al. 1998, Clarke 2002). Hypothalamic-derived GnRH binds the GnRHR, thereby activating the necessary second messenger cascades, which ultimately increase intracellular calcium concentrations necessary to facilitate LH secretion (Anderson 1996). Our study demonstrates that certain PEs, particularly CM, ZR, GN, and DZ, induce estrogen-like effects on gonadotrope responsiveness. One explanation is that PEs increase GnRHR mRNA and expression in the pituitary like $E_{2}$. That this response to $E_{2}$ or the PEs requires one or both of the ER isoforms is suggested by our observation that the responses are attenuated by coincubation with the ER antagonist ICI.

The ER antagonist is commonly used in vivo and in vitro to determine the role of the ER in physiological processes. Upon binding the ER, ICI prevents the receptor dimerization necessary for gene expression (Dauvois et al. 1993, Osborne et al. 2004). Furthermore, ICI effectively inactivates the ER by blocking the AF1 and AF2 transcription activation domains and ultimately increases ER degradation (Osborne et al. 1995, Wakeling 1995). Collectively, these effects of ICI block the effective action of residual ERs. We observed that ICI blocked the effects of $\mathrm{E}_{2}$ and maximum concentrations of $\mathrm{CM}, \mathrm{ZR}$, and GN. Our data illustrate that ICI combined with estrogenic stimuli blocked the suppression of basal FSH secretion and total

Published by Bioscientifica Ltd. 
production of FSH. This suggests that ICI prevents estrogenic stimuli from attenuating activin $\beta$ transcription.

Interestingly, ICI exhibited biphasic responses on gonadotrope responsiveness. When estrogenic stimuli were combined with ICI, we recorded a decrease in responsiveness. This observation indicates that $\mathrm{E}_{2}$ and the PEs exert their effect by interacting with one or both of the ER isoforms in gonadotrope cells. In contrast, ICI alone induced a modest, but significant and repeatable, enhancement of gonadotrope responsiveness and suggests that ICI functions as a partial agonist in our in vitro pituitary cell culture system. Although most studies indicate that ICI functions as a pure ER antagonist, recent observations demonstrate that ICI may have partial agonist activity at some tissues. For example, research conducted using rat primary hippocampal neurons also demonstrated that ICI exhibits agonistic activity (Zhao et al. 2006).

It is important to note that our in vitro cell culture system comprises a heterogeneous population of pituitary cells. The gonadotrope cells predominately express ER $\alpha$ and, therefore, are likely to respond directly to estrogenic inputs (Tobin et al. 2001, Clarke 2002). However, many other pituitary cells, including somatotropes and lactotropes, also express ERs and also have the capacity for direct response to estrogens (Tobin et al. 2001, Zárate \& Seilicovich 2010) or antiestrogens like ICI. This raises the possibility that paracrine signals from adjacent pituitary cells may impinge on the gonadotropes to modulate various aspects cell of function. In this mixed cell system, the measurable parameters, like gonadotrope responsiveness and basal secretion of $\mathrm{LH}$ and FSH, may represent the cumulative effect of direct action of estrogens and antiestrogens on gonadotrope cells and indirect estrogenic responses mediated by estrogen-controlled paracrine factors produced by other pituitary cells.

In conclusion, our study illustrates that PEs decrease basal FSH secretion and total FSH production in a manner that is comparable to $\mathrm{E}_{2}$. This action is blocked when $\mathrm{E}_{2}$ or PE are combined with the ER antagonist, ICI. Our study also shows that PEs increase gonadotrope responsiveness to the GnRH-A in a manner that is similar to $E_{2}$, and this effect is partially reversed by ICI. Our continuing studies are examining the relative important of specific ER isoforms in the expression of the multifaceted effects of estrogens on gonadotrope function.

\section{Declaration of interest}

The authors declare that there is no conflict of interest that could be perceived as prejudicing the impartiality of the research reported.

\section{Funding}

This research was supported by a HATCH Project grant (RR-4505) from the USDA.

\section{References}

Adams TE, Kinder JE, Chakraborty PK, Estergreen VL \& Reeves JJ 1975 Ewe luteal function influenced by pulsatile administration of synthetic LHRH/FSHRH. Endocrinology 97 1460-1467. (doi:10.1210/ endo-97-6-1460)

Adams TE, Wagner TO, Sawyer HR \& Nett TM 1979 GnRH interaction with anterior pituitary. II. Cyclic AMP as an intracellular mediator in the GnRH activated gonadotroph. Biology of Reproduction 21 735-747. (doi:10.1095/biolreprod21.3.735)

Adams TE, Quirke JF, Hanrahan JP, Adams BM \& Watson JG 1988 Gonadotropin-secretion during the periovulatory period in Galway and Finnish Landrace ewes, and Finnish Landrace ewes selected for high ovulation rate. Journal of Reproduction and Fertility 83 575-584. (doi:10.1530/jrf.0.0830575)

Anderson L 1996 Intracellular mechanisms triggering gonadotrophin secretion. Reviews of Reproduction 1 193-202. (doi:10.1530/ ror.0.0010193)

Arreguin-Arevalo JA, Davis TL \& Nett TM 2007 Differential modulation of gonadotropin secretion by selective estrogen receptor 1 and estrogen receptor 2 agonists in ovariectomized ewes. Biology of Reproduction $\mathbf{7 7}$ 320-328. (doi:10.1095/biolreprod.107.060046)

Baratta M, West LA, Turzillo AM \& Nett TM 2001 Activin modulates differential effects of estradiol on synthesis and secretion of folliclestimulating hormone in ovine pituitary cells. Biology of Reproduction 64 714-719. (doi:10.1095/biolreprod64.2.714)

Bates D \& Maechler M 2009 lme4: linear mixed-effects models using S4 classes. R package version 0.999375-32.

Bennetts HW, Underwood EJ \& Shier FL 1946 A specific breeding problem of sheep on subterranean clover pastures in Western Australia. Australian Veterinary Journal 22 2-12. (doi:10.1111/j.1751-0813.1946. tb15473.x)

Clarke IJ 2002 Multifarious effects of estrogen on the pituitary gonadotrope with special emphasis on studies in the ovine species. Archives of Physiology and Biochemistry 110 62-73. (doi:10.1076/apab.110.1.62.898)

Clarke IJ \& Cummins JT 1984 Direct pituitary effects of estrogen and progesterone on gonadotropin secretion in the ovariectomized ewe. Neuroendocrinology 39 267-274. (doi:10.1159/000123990)

Dauvois S, White R \& Parker MG 1993 The antiestrogen ICI 182780 disrupts estrogen receptor nucleocytoplasmic shuttling. Journal of Cell Science 106 1377-1388.

Dixon RA 2004 Phytoestrogens. Annual Review of Plant Biology 55 225-261. (doi:10.1146/annurev.arplant.55.031903.141729)

Huang ES \& Miller WL 1980 Effects of estradiol-17 $\beta$ on basal and luteinizing hormone releasing hormone-induced secretion of luteinizing hormone and follicle stimulating hormone by ovine pituitary cell culture. Biology of Reproduction 23 124-134. (doi:10.1095/biolreprod23. 1.124)

Kuiper GGJM, Lemmen JG, Carlsson B, Corton JC, Safe SH, van der Saag PT, van der Burg B \& Gustafsson J-A 1998 Interaction of estrogenic chemicals and phytoestrogens with estrogen receptor- $\beta$. Endocrinology 139 4252-4263. (doi:10.1210/en.139.10.4252)

Lindzey J, Jayes FL, Yates MM, Couse JF \& Korach KS 2006 The bi-modal effects of estradiol on gonadotropin synthesis and secretion in female mice are dependent on estrogen receptor- $\alpha$. Journal of Endocrinology 191 309-317. (doi:10.1677/joe.1.06965)

Mathieson RA \& Kutts WD 1980 Binding of phyto-oestrogen and oestradiol- $17 \beta$ by cytoplasmic receptors in the pituitary gland and hypothalamus of the ewe. Journal of Endocrinology 85 317-325. (doi:10.1677/joe.0.0850317) 
Miller CD \& Miller WL 1996 Transcriptional repression of the ovine folliclestimulating hormone- $\beta$ gene by $17 \beta$-estradiol. Endocrinology 137 3437-3446. (doi:10.1210/en.137.8.3437)

Miller WL, Knight MM, Grimek HJ \& Gorski J 1977 Estrogen regulation of follicle-stimulating hormone in cell-cultures of sheep pituitaries. Endocrinology 100 1306-1316. (doi:10.1210/endo-100-5-1306)

Moule GR, Braden AWH \& Lamond DR 1963 The significance of oestrogens in pasture plants in relation to animal production. Animal Breeding Abstracts 31 139-157.

Nett TM, Turzillo AM, Baratta M \& Rispoli LA 2002 Pituitary effects of steroid hormones on secretion of follicle-stimulating hormone and luteinizing hormone. Domestic Animal Endocrinology 23 33-42. (doi:10.1016/S0739-7240(02)00143-1)

Osborne CK, Coronado-Heinsohn EB, Hilsenbeck SG, McCue BL, Wakeling AE, McClelland RA, Manning DL \& Nicholson RI 1995 Comparison of the effects of a pure steroidal antiestrogen with those of tamoxifen in a model of human breast cancer. Journal of the National Cancer Institute 87 746-750. (doi:10.1093/jnci/87.10.746)

Osborne CK, Wakeling A \& Nicholson RI 2004 Fulvestrant: an oestrogen receptor antagonist with a novel mechanism of action. British Journal of Cancer 90 S2-S6. (doi:10.1038/sj.bjc.6601629)

Sakurai H \& Adams TE 1991 Gonadotrope responsiveness in orchidectomized sheep: I. Effect of continuous infusion of estradiol. Biology of Reproduction 45 804-810. (doi:10.1095/biolreprod45.6.804)
Tobin VA, Pompolo S \& Clarke IJ 2001 The percentage of pituitary gonadotropes with immunoreactive oestradiol receptors increases in the follicular phase of the ovine oestrous cycle. Journal of Neuroendocrinology 13 846-854. (doi:10.1046/j.1365-2826.2001.00701.x)

Turzillo AM, Nolan TE \& Nett TM 1998 Regulation of gonadotropinreleasing hormone $(\mathrm{GnRH})$ receptor gene expression in sheep: interaction of GnRH and estradiol. Endocrinology 139 4890-4894. (doi:10.1210/en.139.12.4890)

Wakeling AE 1995 Use of pure antioestrogens to elucidate the mode of action of oestrogens. Biochemical Pharmacology 49 1545-1549. (doi:10.1016/0006-2952(94)00528-T)

Zárate S \& Seilicovich A 2010 Estrogen receptors and signaling pathways in lactotropes and somatotropes. Neuroendocrinology 92 215-223. (doi:10.1159/000321683)

Zhao L, O'Neill K \& Brinton RD 2006 Estrogenic agonist activity of ICI 182780 (Faslodex) in hippocampal neurons: implications for basic science understanding of estrogen signaling and development of estrogen modulators with a dual therapeutic profile. Journal of Pharmacology and Experimental Therapeutics 319 1124-1132. (doi:10.1124/jpet.106.109504)

Zhou W, Wang G, Han Z, Yao W \& Zhu W 2009 Metabolism of flaxseed lignans in the rumen and its impact on ruminal metabolism and flora. Animal Feed Science and Technology 150 18-26. (doi:10.1016/ j.anifeedsci.2008.07.006)

Received in final form 16 September 2013

Accepted 18 September 2013

Accepted Preprint published online 19 September 2013
(C) 2013 Society for Endocrinology Printed in Great Britain 